DOI: $10.1515 /$ rpp-2015-0060

Doctor of Philosophical Sciences, Full Professor, NATALIA PETRUK Khmelnytskyi National University, Ukraine Address: 11 Instytutska St., Khmelnytskyi, 29016, Ukraine E-mail: nataliia.petruk@gmail.com

\title{
IDEAS ON MORAL AND CIVIL UPBRINGING OF PERSONALITY IN ITALIAN AND UKRAINIAN PEDAGOGY DURING THE RENAISSANCE
}

\begin{abstract}
Important aspects of moral and civic upbringing of personality based on studying the experience of humanist pedagogy establishment in the Italian Renaissance in XIV-XV centuries and the Ukrainian Renaissance in XVI-XVII centuries have been reviewed in the article. It has been found out that under the influence of Renaissance in XVI-XVII centuries Ukrainian pedagogy progressed not only in the Orthodox Christian paradigm of thinking, but was greatly enriched by the humanistic ideas of European origin as well and the matter of a person, a bright personality, endowed with unique personality traits, high ethical and Christian virtues, active and dynamic, was crucial for the forming of humanistic pedagogy. This resulted in increasing interest of Ukrainian philosophers to human problems, establishment of the value of personality, awareness of the importance of education and science in life. Intellect, education, moral virtues and work became the greatest personal qualities in works of Italian and Ukrainian humanists. Pedagogical culture during the Renaissance was also determined by ideas of civil humanism, need for patriotic education and personal action for the common good. Formation of civic sense and responsibility for own actions were of great importance.
\end{abstract}

Key words: Renaissance, Renaissance culture, humanism, humanistic pedagogy, personality, intellect, civic humanism, ethics.

\section{INTRODUCTION}

Current trends in Ukrainian education and pedagogy connected with the integration into European cultural and educational process highlight the important matter of educating an ethical personality with a distinct civic position and national identity. Such personality acts as a carrier of humanistic culture, demonstrates and implements civic service and patriotism in his/her activity. The awareness of the need for educating personality in modern Ukrainian pedagogy is consistent with the understanding of the need for using high achievements of European educational thought. One of the important consequences of this becomes an opportunity for better understanding the spiritual world of Ukrainian nation and forming the best spiritual and moral characteristics based on that as well as awareness of the unity with European culture and separation from spiritual isolation and national constraints.

Study and creative use of the ideas of European and Ukrainian pedagogy of past centuries is essential, given the task of upbringing of personality, forming of his/her identity as well as moral and civic characteristics. Pedagogical heritage of the Renaissance has the undoubted value in this regard.

\section{THE AIM OF THE STUDY}

The aim of this paper is to study important aspects of ethical and civic upbringing of personality in the context of Ukrainian and Italian pedagogical development during the Renaissance. 


\section{THEORETICAL FRAMEWORK AND RESEARCH METHODS}

This article is an example of an interdisciplinary approach to the analysis of the outlined problem and is based on the principle of the unity of philosophical, historical and pedagogical knowledge. The integrated nature of the study makes it possible to perceive the phenomenon of Renaissance pedagogy as whole, and also to examine the specificity of Ukrainian pedagogical thought development in the context of European culture. The analysis of this particular issue is based on the study of original sources - works of Italian humanists of XIV-XV centuries and Ukrainian humanists of XVI-XVII centuries.

\section{RESULTS}

Intensive integration of Renaissance humanistic ideas in Ukraine begins in XVI-XVII centuries. Through the activity of intellectual, scientific and literary elite Ukraine acquires pedagogical culture of European level; national consciousness emerges; the ideal of personal ethical education obtains civic nature. Even so, natural relations of Ukrainian culture with Kyiv Rus traditions and Orthodox spirituality are kept. Special "openness" and ability to synthesize Western European Renaissance ideas of purely national consciousness characterize Ukrainian consciousness and educational thought of that time. Ukrainian humanism, as well as European, is soaked with ideas of human values and the need for education of personality based on high morality, civic sense and patriotism.

The Renaissance became that important era in the history of European culture, when the great revolution in the human values system happened, when fundamentally new vision of the world, society and person was formed. Originating in Italy, the Renaissance had had a big influence on the development of many Eastern European cultures, including Ukrainian. Therefore, phenomena and processes of the Renaissance origin are observed in Ukrainian culture and pedagogy of XVI-XVII centuries (Литвинов, 2000). Humanism as a set of moral and ethical studies of a person, his/her place in the world, education, ways of achieving human happiness, became the foundation of the Renaissance. Italian humanism regarded a person as something that carries harmony of a spirit and body, as the highest value and creator of his/her own fate.

Despite the fact that Ukrainian culture was predisposed more to north European Renaissance than Italian, pedagogical thought of Ukraine during XVI-XVII centuries had the imprint of Italian humanist's opinion about personality. Certainly, reconsideration and alteration of European ideological humanistic forms with their further adjusting to the distinctiveness of Ukrainian thinking and the needs of the national spiritual culture occurred.

Renaissance worldview in general was based on the idea of personality's selfassertion, protection of his/her rights, dignity, ethical and civic education. Development of personality and improvement of his/her moral virtues were given the most attention in the works of prominent representatives of Italian humanism, namely, L. Alberti, P. Guicciardini, P. della Mirandola, L. Valla and others. Principles of humanistic ethics were also defined by ideas of human coexistence, harmony, serving of personality to the common good, recognizing the need of personality to yield to the interests of society.

The theme of personality and ethical content of his/her consciousness becomes central in the works of Italian humanists of XV century. Humanistic ethics and pedagogy became those areas where such ethical categories as intelligence, virtue, good and evil developed. In particular, interesting aspects of understanding the personality and ways of his/her education are found in the work of the famous Italian humanism theorist L. Alberti "Della famiglia". L. Alberti believed that the foundations of excellence are embedded by nature and a person is expected to reveal them during his/her life. This excellence is based 
on such human qualities as virtue and intelligence. According to L. Alberti, of all spiritual qualities, it is intelligence that leads personality to acquiring the truth and to the good deeds and creates a solid foundation of freedom (Alberti, 1962). In addition, intelligence is always an important characteristic of human personality.

A truly natural, vital principle for personality was considered to be that moral virtue, components of which were justice, temperance, courage, fortitude and patience. Emphasizing the importance and benefits of virtue (virtu) for the personality and society, L. Alberti underlines its independence from external benefits such as wealth, nobility, power (Alberti, 1960). Virtue is natural and thus public: anyone can become virtuous if they wish to. Despite the fact that virtue is a personal quality, it always appears in personality's attitude to the society. It keeps and maintains the harmony of people with the world. Virtue is by nature incompatible with the egoism that brings harm to others (Alberti, 1960). By developing a moral character, people attain harmony with the world. The responsibility for moral perfection rests with personality.

Activity becomes an important ethical and pedagogical norm of personality in the Renaissance. New meaning of humanistic pedagogy is vested in the work evaluation. Work for humanists is an important ethical norm of each person regardless of his/her state or status. Humanists saw the welfare foundation of man and society as well as sustainable foundation of culture development in dynamic secular activity. "Man is not born to do nothing but to act", believed L. Alberti (Alberti, 1960). Only by activity, through disclosure of creative abilities, the ultimate goal of human life - happiness - can be achieved. Humanists saw the basis of personality's and society's vital functions as well as perspective of cultural development in activity.

Thus, Italian Renaissance humanists' high evaluation of personality, his/her natural abilities, intelligence and moral virtues point out the goal of European pedagogy of that time - the forming and education of person as a whole. Studia humanitatis, a set of human sciences, acquires the highest value, becomes that necessary condition for achieving genuine culture as opposed to "holy rudeness" of faith and ignorance (Garin, 1971). Empowering personality with high essential forces, ethical characteristics and civic qualities indicated that new thinking as well as completely new European pedagogical discourse on education emerged.

A significant consequence for spreading humanistic ideas in Ukraine became interest in the problems of personality and his/her upbringing. Ethical and pedagogical ideas of Western European Renaissance found their extension in Ukrainian version of the Renaissance humanism that was spreading during XVI-XVII centuries. Ideas of moral, patriotic and civic education of personality became an organic part of Ukrainian pedagogical culture. This applies to the works of I. Dombrovsky, S. Klenovich, S. Orikhovsky, S. Pekalid, K. Sakovych, M. Smotrytsky.

Being well-educated people and relying on traditions of ancient philosophy, Ukrainian philosophers paid attention not only to matters of educating faith and Christian virtues but also to problems of purely earthly human life. The value of the person, in their opinion, was not in gentility, aristocracy or wealth but in high moral virtues, intelligence and education, civic service for the benefit of the homeland (Українські гуманісти епохи Відродження, 1995). It is not surprising that ideas of civic humanism were propagated in works of many Ukrainian philosophers of XVI-XVII centuries. Ideas of serving the common good, homeland, the people became fundamental in pedagogical and educational movement of Ukrainian scribes, members of Ukrainian fraternities and cultural educational organizations in 
Ukraine. Spreading of the outlook that was based on ideas of civic humanism has contributed to the formation of national consciousness of Ukrainians as well as to understanding the importance of knowledge of their own history in cultivating a citizen, in the development of national education and culture.

A thought that the forming of personality as a moral entity is a complicated process has emerged in Ukrainian pedagogical thought of XVI-XVII centuries. Without questioning basic Christian virtues - love, compassion, brotherhood - and considering the teaching of those to be the main purpose of a Christian, Ukrainian philosophers valued intelligence, knowledge and secular education at the same time. These human virtues were a major advantage in improving the personality, his/her withdrawal from the world of ignorance, cruelty and violence.

The distinguishing feature of Ukrainian humanistic pedagogy was the recognition of transience of human life and understanding of its use for specific noble acts, for implementation of a man's life designation. Therefore, activities of several prominent people of that time, courageous princes and warriors, - K. Ostrozkyi, M. Vyshnevetsky, hetman P. Konashevych-Sahaidachny - were idealized (Українські гуманісти епохи Відродження, 1995).

Another important premise for the forming of humanistic pedagogy principles in Ukraine was the conclusion that good and evil are not always abstract characteristics within the framework of personality. They appear in certain actions and have very specific content. And ethical categories, within which humanistic education operates, arise as a great part of human life. In general, a person was in the center of conflict between good and evil and the history became the arena for human affairs and actions, for the battle of human passions, for aspiration and interests. Such human virtues as dignity, talent, genius, intelligence, courage and bravery started to be valued. Due to these virtues, people were able to influence the course of events, to direct and to alter them on their own.

The idea of humanistic pedagogy about acquiring high moral virtues at an early age (in childhood) was especially important from the perspective of ethical education of personality. This stimulated the search for different ways, forms and methods of younger generation's education. Science, especially philosophy served as one of the most important means of education. It was believed that future character of a person depends on moral principles that were embedded during childhood. This thought was consonant with the views of the German humanist Erasmus of Rotterdam on the problems of education.

\section{CONCLUSIONS}

Thus, there are good reasons to include Ukrainian pedagogical thought of XVI-XVII centuries into the context of the European Renaissance. The matter of a person, a bright personality, endowed with unique personality traits, high ethical and Christian virtues, active and dynamic, was crucial for the forming of humanistic pedagogy. Under the influence of the Renaissance ideas Ukrainian pedagogy was focused on the perception of a man as a part of social life that not only seeks to satisfy his personal needs but also acts for common goals and for the common good (civic humanism). It can be stated that Ukrainian pedagogical discourse of XVI-XVII centuries was consistent with the main pan-European trends of cultural progress of the Renaissance, and that the works of Ukrainian humanists became the stimulus for the Ukrainian community entering into the circle of enlightened European nations.

Perspectives for further researches we consider the study of the influence of Western pedagogy on the development of Ukrainian pedagogy. 


\section{REFERENCES}

1. Alberti, L. (1960). I libri della famiglia. Opert volgari [Thoughts on Family. The Collections of Works]. Volume 1. Laterza, 472 p. (in Italian).

2. Garin, E. (1971). Educazione umanistica in Italia [Humanistic Education on Italy]. Bari, 120 p. (in Italian).

3. Kristeller, P. (1974). Humanismus und Renaissance [Humanism and Renaissance]. München : Fink, 539 p. (in German).

4. Lytvynov, V. (2012). Ukraine: Seeking Its Identity. The 16th-Early 17th Centuries. Historical and Philosophical Essay. Kуiv : Академперіодика, 510 p.

5. Литвинов, В. (2000). Ренесансний гуманізм в Украӥні [Renaissance Humanism in Ukraine]. К. : Основи, 468 р. (in Ukrainian).

6. Украӥнські гуманісти епохи Відродження. Антологія [Ukrainian Humanists of the Renaissance. Anthology]. (1995). К. : Наукова думка; Основи. Part 1, p. 431; Part 2, 430 p. (in Ukrainian). 